University of Nebraska - Lincoln

DigitalCommons@University of Nebraska - Lincoln

\title{
The role of glutamate and its receptors in mesocorticolimbic dopaminergic regions in opioid addiction
}

\author{
Yuan Guo \\ Xi'an Jiaotong University School of Medicine \\ Hui-Ling Wang \\ Xi'an Jiaotong University School of Medicine \\ Xiao-Hui Xiang \\ Medical College of Chinese People's Armed Police Forces \\ Yan Zhao \\ Xi'an Jiaotong University School of Medicine
}

Follow this and additional works at: https://digitalcommons.unl.edu/publichealthresources

Part of the Public Health Commons

Guo, Yuan; Wang, Hui-Ling; Xiang, Xiao-Hui; and Zhao, Yan, "The role of glutamate and its receptors in mesocorticolimbic dopaminergic regions in opioid addiction" (2009). Public Health Resources. 106. https://digitalcommons.unl.edu/publichealthresources/106

This Article is brought to you for free and open access by the Public Health Resources at DigitalCommons@University of Nebraska - Lincoln. It has been accepted for inclusion in Public Health Resources by an authorized administrator of DigitalCommons@University of Nebraska - Lincoln. 


\title{
Review
}

\section{The role of glutamate and its receptors in mesocorticolimbic dopaminergic regions in opioid addiction}

\author{
Yuan Guo ${ }^{a}$, Hui-Ling Wang ${ }^{\mathrm{a}, \mathrm{b}}$, Xiao-Hui Xiang ${ }^{\mathrm{c}}$, Yan Zhao ${ }^{\mathrm{a}, *}$ \\ ${ }^{a}$ Department of Physiology and Pathophysiology, Xi'an Jiaotong University School of Medicine, Xi'an, Shaanxi 710061, PR China \\ ${ }^{\mathrm{b}}$ Intramural Research Program, Cellular Neurophysiology, National Institute on Drug Abuse, Biomedical Research Center, Baltimore, MD 21224, USA \\ ${ }^{\mathrm{c}}$ Department of Physiology and Pathophysiology, Medical College of Chinese People's Armed Police Forces, Tianjin 300162, PR China
}

\section{A R T I C L E I N F O}

\section{Article history:}

Received 23 October 2008

Received in revised form 10 February 2009

Accepted 19 February 2009

\section{Keywords:}

Opioid addiction

Mesocorticolimbic dopaminergic regions

Glutamate

Glutamate receptor

\begin{abstract}
A B S T R A C T
Accumulating evidence suggests that glutamate, as one of the most important excitatory neurotransmitters in the brain, plays a key role in drug addiction including opioid addiction. There is substantial evidence for glutamatergic projections into mesocorticolimbic dopaminergic neurons, which are associated with opioid psychological dependence and are also the key regions of enhancement effect. Glutamate may be involved in the process of opioid addiction not only by acting on its ionotropic and metabotropic glutamate receptors that activate several signal transduction pathways, but also by interacting with other neurotransmitters or neuropeptides such as opioids, dopamine, $\gamma$-aminobutyric acid and substance $P$ in the mesocorticolimbic dopaminergic regions. Studies on the role of glutamate and its receptors in opioid addiction will provide a new strategy for the exploitation of drugs for the treatment of opioid addiction.
\end{abstract}

(c) 2009 Elsevier Ltd. All rights reserved.

\section{Contents}

1. Introduction . . . . . .

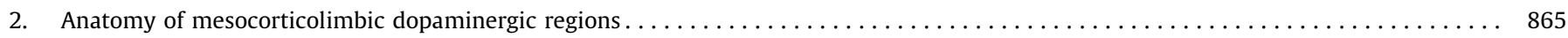

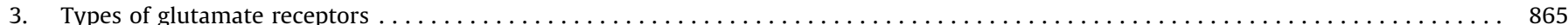

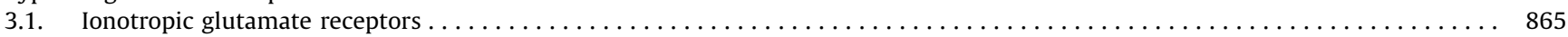

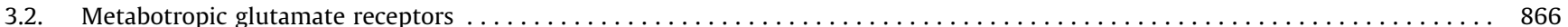

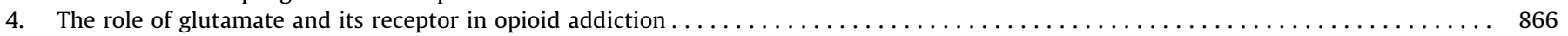

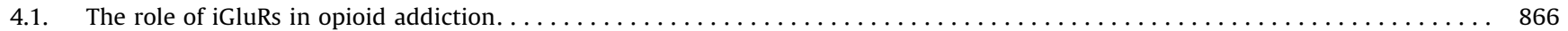

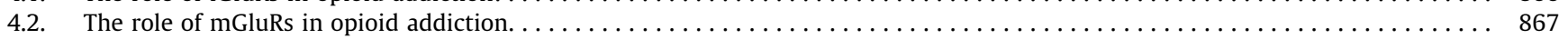

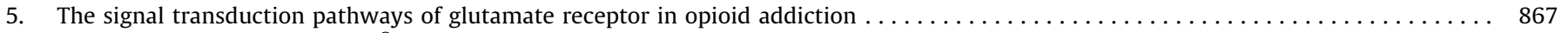

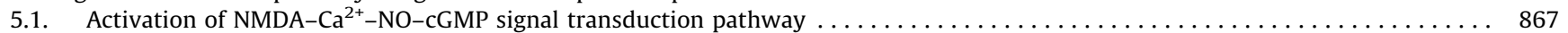

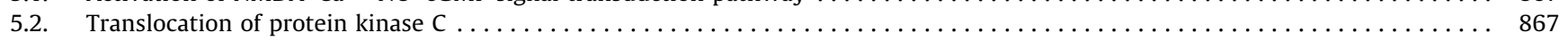

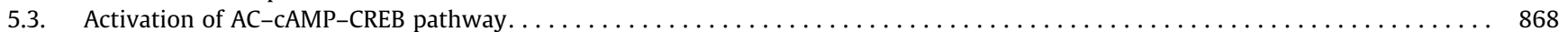

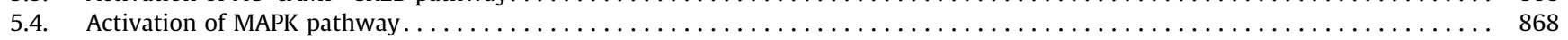

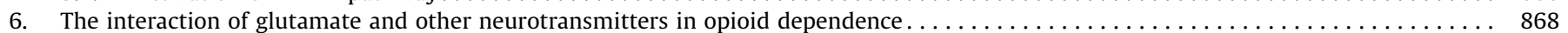

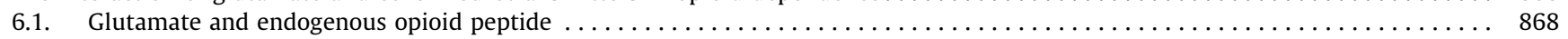

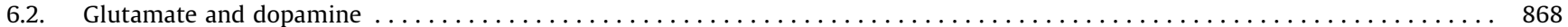

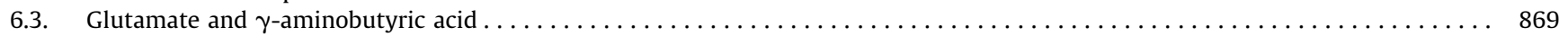

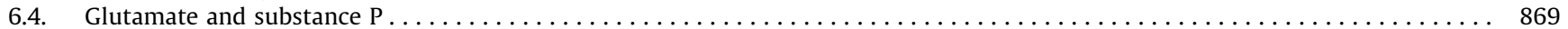

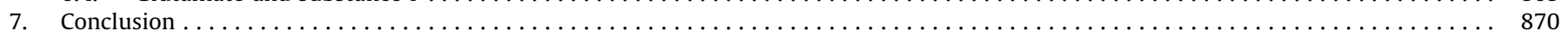

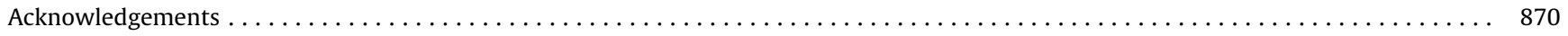

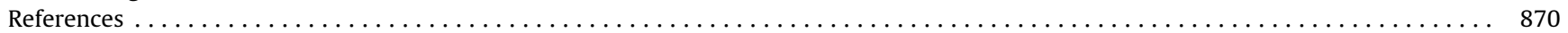

* Corresponding author. Tel.: +8629 82655171; fax: +862982656364.

E-mail address: zhaoy502@mail.xjtu.edu.cn (Y. Zhao). 


\section{Introduction}

Drug addiction is a kind of chronic relapsing brain disease characterized by the loss of control over drug intake, repeated unsuccessful attempts at quitting or reducing drug use, continued drug use despite negative consequences, reduction in engagement in social, occupational and recreational activities in lieu of drugseeking or self-administration behavior, and the emergence of symptoms of tolerance or withdrawal (American Psychiatric Association, 1994; Koob and Nestler, 1997; Koob et al., 1998, 2004; Gass and Olive, 2008). Some addictive drugs such as opioid, cocaine, cannabinoids, heroin, amphetamine and nicotine can produce physical and psychological dependence (Dackis and Gold, 1985; Koob, 1992; Di Chiara, 1995; Wise, 1996; Manzanares et al., 1999). Although opioids are useful analgesics for clinical use, major problems associated with the chronic use of opioids are tolerance and dependence. In addition, long-term use of opioids can lead to serious physical and psychological dependence, limiting the usage of opioids and causing an adverse impact on the society (Ree et al., 1999). Therefore, research on the neurobiological mechanism and treatments of opioid dependence have been vigorous.

Since all addictive drugs facilitate dopamine (DA) transmission, determining the role of DA has been the predominant focus of biomedical research in addiction for the past 20 years (Kalivas, 2004). Recently, accumulating evidence indicates that glutamate plays an important role in drug addiction especially in latest 5 years (Tzschentke and Schmidt, 2003; Gass and Olive, 2008). Glutamate is one of the most abundant excitatory neurotransmitters in the brain, mediating as much as $70 \%$ of the synaptic transmission within the central nervous system (Fonnum, 1984; Cotman et al., 1987; Headley and Grillner, 1990; Gass and Olive, 2008). There are glutamatergic projections and/or neurons expressing glutamate receptors in some regions of the brain, including the mesocorticolimbic dopaminergic regions (Heimer et al., 1997; Wolf, 1998; Groenewegen et al., 1999; Geisler et al., 2007; Kalivas and O'Brien, 2008), which provide an anatomical basis for the role of glutamate in addiction.

Drug addiction is a complex process. Interaction of many brain nuclei with neurotransmitters or neuropeptides constitutes a neural network, which affects the intracellular signal transduction and is involved in drug addiction including opioid addiction (De Vries and Shippenberg, 2002; Kalivas, 2004; Wang et al., 2005). Many brain regions are involved in the opioid addiction including locus ceruleus, periaqueductal gray, medial thalamus, hypothalamus, amygdala (AMY), globus pallidus, nucleus raphe magnus, gigantocellular reticular nucleus, ventral tegmental area (VTA), nucleus accumbens (NAc) and substantia nigra (Temple and Zukin, 1987; Nestler and Aghajanian, 1997; Ivanov and Aston-Jones, 2001; Koob, 2003). Among these brain regions, the VTA and NAc, important components of mesocorticolimbic dopaminergic regions, are prominent regions to opioid psychological dependence and also thought to serve as key regions for mediating reinforcement processes (Harris and Aston-Jones, 1994; Grant et al., 1996; De Vries and Shippenberg, 2002; Spanagel and Weiss, 2002). This review will summarize recent research progress on the role and mechanism of glutamate and its receptors in the mesocorticolimbic dopaminergic regions in opioid addiction.

\section{Anatomy of mesocorticolimbic dopaminergic regions}

Mesocorticolimbic dopaminergic pathway is composed of VTA dopaminergic neurons and its projections, the NAc, AMY and the medial prefrontal cortex (mPFC), in which the VTA and NAc are the important nuclei involved in a variety of reward effects (Kalivas, 1993; White, 1996; Bjorklund and Dunnett, 2007). When the VTA, NAc and central or lateral nucleus of amygdala were lesioned with a DC current, morphine-induced conditioned place preference (CPP) can be inhibited (Wang et al., 2002). Morphological study showed that the both volume and number of neurons in the VTA and NAc in morphine withdrawal rats decreased (Spiga et al., 2003). There are also evidence that indicates drug-seeking in morphine-dependent rats and heroin-induced self-administration are related to the electrical activities of DA neurons in the VTA and NAc (Chang et al., 1997; Kiyatkin and Rebee, 2001). The DA level in the VTA and NAc decreased in morphine withdrawal rats, while increased in morphine-dependent rats during drug-seeking (Acquas and Di Chiara, 1992; Herz et al., 1992; Shaham et al., 1996). These results indicate that the mesocorticolimbic dopaminergic regions play important roles in the development of morphine dependence and during withdrawal.

DA neurons are abundant in the VTA (A10), receiving afferent fiber projections from the cortex, thalamus, striatum, limbic system and the brain stem. They also project widely to NAc, mPFC, piriform cortex, hippocampus, entorhinal cortex, amygdala, hallux rigidus and brain stem (including locus coeruleus, parabrachial nucleus and nuclei of median raphe), etc. Not only dopaminergic neurons (Fallon and Moore, 1978; Swanson, 1982; Margolis et al., 2006) but also GABAergic and glutamatergic neurons are cytochemically identified in the VTA (Van Bockstaele and Pickel, 1995; Carr and Sesack, 2000; Margolis et al., 2006; Yamaguchi et al., 2007). It has also been shown that glutamate can be released by some VTA neurons (Chuhma et al., 2004; Lavin et al., 2005; Fields et al., 2007).

The NAc contains three functionally distinct subcompartments, termed as the shell, core and rostral column based on anatomical and biochemical differences (Jongen-Relo et al., 1993, 1994; Voorn et al., 1994; Meredith et al., 1996). The shell region of NAc mainly received dopaminergic projections from the VTA, while the core region of NAc mainly received excitatory glutamatergic projections from amygdala and hippocampus (Kelley et al., 1982; Swanson, 1982; Phillipson and Griffiths, 1985; Groenewegen et al., 1987). Most of the neurons in NAc are GABAergic (O'Donnell and Grace, 1993; Pennartz et al., 1994). Within the NAc, the core subcompartment has the strongest association with drug-seeking (Di Ciano et al., 2001; Everitt et al., 2001). There are two categories of adaptation in glutamate transmission in the NAc: one of which promotes presynaptic glutamate release and the other alters postsynaptic responsiveness to released glutamate. It is proposed that the glutamatergic projection from the mPFC to the NAc is a final common pathway for eliciting drug-seeking behaviors (Kalivas and Volkow, 2007).

The major dopaminergic, glutamatergic and GABAergic efferent and afferent projections in mesocorticolimbic dopaminergic pathway including VTA, NAc, mPFC and AMY are shown in Fig. 1.

\section{Types of glutamate receptors}

Glutamate is one of the most abundant excitatory neurotransmitters in the central nervous system. Once released into the synaptic cleft, glutamate can bind to its receptors and exert its effect. According to pharmacological and molecular biological classification, glutamate receptors can be divided into two categories, ionotropic glutamate receptors (iGluRs) and metabotropic glutamate receptors (mGluRs).

\subsection{Ionotropic glutamate receptors}

Ionotropic glutamate receptors are ligand-gated ion channels and are divided into three subtypes: $N$-methyl-D-aspartic acid (NMDA), $\quad \alpha$-amino-3-hydroxy-5-methyl-4-isoxazole-propionic acid (AMPA) and kainic acid (KA). The latter two are also referred 


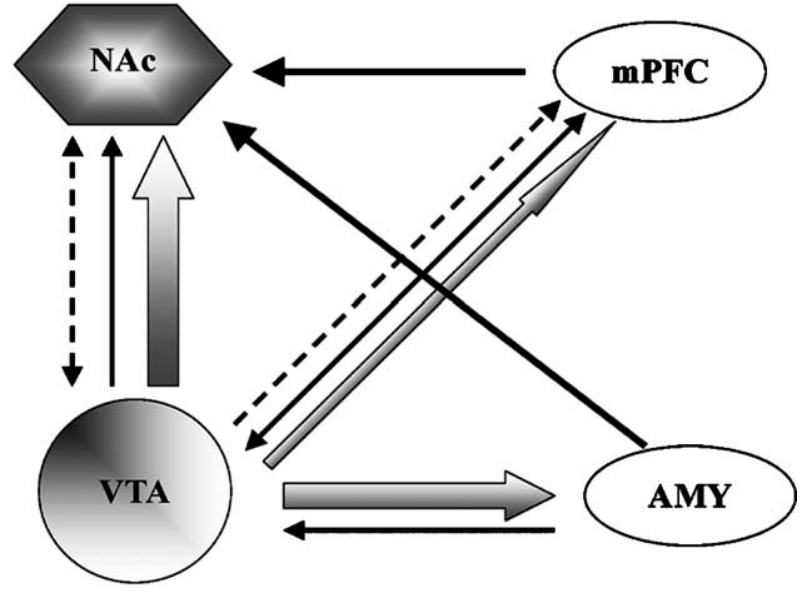

Fig. 1. Major nucleuses and efferent and afferent projections in mesocorticolimbic dopaminergic pathway. Dopaminergic efferent and afferent are shown in hollow arrow; glutamatergic efferent and afferent are shown in black arrow; GABAergic efferent and afferent are shown in arrow with dash line. Circle means the neurons in VTA are mainly identified as dopaminergic neurons and the hexagon means the neurons in NAc are mainly identified as GABAergic and some peptidergic neurons. VTA: ventral tegmental area; NAc: nucleus accumbens; AMY: amygdala; mPFC: medial prefrontal cortex.

to non-NMDA receptors (Monaghan et al., 1989; Young and Fagg, 1990; Seeburg, 1993).

NMDA receptors are heterotetrameric protein complexes that form ligand-gated ion channels composed of at least one basic subunit NR1 and regulating subunits NR2 (Dingledine et al., 1999; Stephenson, 2006; Paoletti and Neyton, 2007). NR1 subunit is the common subunit while NR2 subunit determines the pharmacological specificity of the NMDA receptor. There are four types of NR2 subunits named as NR2A, NR2B, NR2C and NR2D (Monyer et al., 1992; Nakanishi, 1992). Recently, two new members of gene families that code NMDA receptor subunits were cloned and named as NR3A and NR3B. They may be involved in the composition of NMDA receptors (Sucher et al., 1996; Myers et al., 1999; Madden, 2002). NMDA receptors are coupled with ion channels including sodium ions, potassium ions and calcium ions. These receptors induce excitatory postsynaptic potential (EPSP). Endogenous agonists of the NMDA receptors are glutamate, aspartate and quinaldinic acid. The activity of NMDA receptors is regulated not only by the endogenous and exogenous agonists but also by the binding position of ions and molecules such as $\mathrm{Mg}^{2+}, \mathrm{Zn}^{2+}, \mathrm{H}^{+}$, glycine and polyamine.

AMPA receptors are heterotetrameric protein complexes that form ligand-gated ion channels composed of various subunits termed as GluR1-4 (also termed as GluRA-D) and GluR $\delta 1$ and 2 (Dingledine et al., 1999). Kainic acid (kainate, KA) receptors are tetrameric protein complexes that form ligand-gated ion channels composed of various subunits. These subunits are termed as GluR5-7 and KA1 and 2 (Kenny and Markou, 2004). Like NMDA receptors, AMPA and KA receptors are permeable to $\mathrm{Na}^{+}$and $\mathrm{K}^{+}$ ions and are able to trigger EPSP.

\subsection{Metabotropic glutamate receptors}

The mGluRs are G-protein-coupled receptors. Besides having the same sequence characteristics of seven transmembrane regions, these receptors have no homology with other Gprotein-coupled receptors. According to sequence similarities, priorities of agonists and the intracellular signal transduction pathway, eight kinds of mGluRs can be divided into three groups (I, II and III; Schoepp et al., 1990; Conn and Desai, 1991; Miller, 1994; Pin and Duvoisin, 1995; Conn and Pin, 1997). Group I mGluRs
(mGluR1 and 5) are predominately located postsynaptically and couple to Gq proteins. They mainly hydrolyze inositol phosphate (PI) into intracellular second messengers diacylglycerol and 1,4,5inositol trisphosphate $\left(\mathrm{IP}_{3}\right)$ through the activation of phospholipase C (Conn and Pin, 1997; Hermans and Challiss, 2001; Coutinho and Knopfel, 2002). Group I mGluRs also can couple to intracellular Homer proteins, possibly through a Homer-phosphatidylinositol 3-kinase (PI3K) enhancer adaptor complex (Xiao et al., 2000; Rong et al., 2003). Group II mGluRs (mGlu2 and 3 ) are found both preand postsynaptically and group III mGluRs (mGlu4, 6, 7 and 8) are predominately located presynaptically. Both of them couple to $\mathrm{Gi} / \mathrm{o}$ proteins to negatively regulate the activity of adenylyl cyclase (AC) and decrease the content of cAMP (Schoepp, 2001; Mudo et al., 2007; Gass and Olive, 2008). The mGluRs can also promote cGMP production, activation of phospholipase $\mathrm{D}$ and the release of arachidonic acid (Conn and Pin, 1997; Madden, 2002; Pin and Acher, 2002; Jingami et al., 2003).

\section{The role of glutamate and its receptor in opioid addiction}

It is known that certain glutamatergic projection could be impacted by addictive drugs. Data indicate that the activation of glutamatergic efferent fibers from the amygdala and prefrontal cortex is critical in the expression of addictive behaviors (Pierce and Kalivas, 1997; Goldstein and Volkow, 2002; McLaughlin and See, 2003; See et al., 2003; Kalivas, 2004; Kalivas et al., 2009). The alteration of glutamate-mediated transmission, especially the increase of glutamatergic transmission in the NAc may promote the seeking and relapse from abused drugs (Zhu et al., 1998; Watanabe et al., 2002; Kenny and Markou, 2004; Paul and Athina, 2004). Suaud-Chagny et al. (1992) reported that microinjection of glutamate into the VTA can increase exploratory motor behaviors and the release of DA in NAc and $\mathrm{mPFC}$. These results suggest that glutamate plays an important role in opioids dependence.

\subsection{The role of iGluRs in opioid addiction}

Gudehithlu et al. (1994) first reported the change of NMDA receptors in rat brain following long-term treatment with morphine. Then it was shown that the expression of NMDA receptors was upregulated in morphine-dependent rat brains (Koyuncuoglu et al., 1999). Recently, more studies showed that glutamatergic signal transduction can regulate drug effects, resulting in drug tolerance and dependence, including the tolerance and dependence of opioids. Glutamatergic afferents play a key role in regulating the firing of the VTA neurons. Activation of glutamatergic afferents and the VTA infusion of glutamate receptor agonists increase the firing rates of dopaminergic neurons and induce burst firing in vivo (Grace and Bunney, 1984; Chergui et al., 1993; Murase et al., 1993). It was also demonstrated that MK801, an NMDA receptor antagonist, completely blocked the withdrawal symptoms induced by glutamate and naloxone (Tokuyama et al., 1996, 2001). MK-801 can also decrease morphine dependence, which may be related to the downregulation of NMDA receptors (Gudehithlu et al., 1994; Koyuncuoglu et al., 1999). Western blot and microdialysis results showed that chronic intermittent use of morphine, cocaine and other addictive drugs can increase the level of glutamate in the VTA, upregulating the expression of AMPA receptor subtypes GluR1 and NMDAR1 in the VTA (Fitzgerald et al., 1996; Kalivas and Duffy, 1998). Co-application of opioids and NMDA receptor competitive or non-competitive antagonists can block the pain tolerance and physical dependence of opioid and the drug-seeking behaviors (Nestler et al., 2001). Bisaga et al. (2001) indicated that glutamatergic signal transduction mediated by NMDA receptors was involved in the formation and maintenance of morphine 
dependence in human. It was also reported that MK-801 injected into the VTA reduced the morphine-induced CPP, which suggested that ionotropic glutamate receptors in the VTA were involved in the psychological dependence of opioids (Popik and Kolasiewicz, 1999). Our recent studies found that microinjection of NMDA receptor antagonist MK-801 or non-NMDA receptor antagonist DNQX into the VTA partly attenuated morphine withdrawal symptoms induced by naloxone, suggesting that the NMDA and non-NMDA receptors in the VTA are involved in morphine withdrawal process (H.L. Wang et al., 2004). Moreover, systemic and intracerebroventricular injections of NMDA receptor antagonists (MK-801, memantine and dextromethorphan, etc.) and nonNMDA receptor antagonists (DNQX, CNQX, LY293558 and LY215490) prevented some morphine withdrawal symptoms in rats (Fundytus and Coderre, 1994; Rasmussen, 1995; Manning et al., 1996; Bristow et al., 1997; Popik et al., 1998). Microinjection of ionotropic glutamate receptor antagonists MK-801 or DNQX into the VTA attenuated the reinforcement effect in heroin addiction (Xi and Stein, 2002b). Chronic intermittent injection of escalating doses of morphine is accompanied by ultrastructural plasticity of GluR1 in neurons that are responsive to glutamate, activation of DA-induced D1 dopamine receptor in the NAc shell, and activation of neurons capable of responding to glutamate but not to D1 dopamine receptor stimulation in the NAc core (Glass et al., 2008). These results indicate that glutamate released in the central nervous system plays an important role in opioid withdrawal behaviors and that the iGluRs are involved in the process.

\subsection{The role of mGluRs in opioid addiction}

Metabotropic glutamate receptors, which mediate slow glutamate neurotransmission, are located throughout the limbic and cortical brain regions implicated in drug addiction. There is significant pharmacological and behavioral evidence that group I mGluRs are widely distributed in the projection neurons and intermediate neurons in the shell and core of NAc, providing the morphological evidence for their regulation and therapic effects in reward-related behaviors and drug addiction (Mitrano and Smith, 2007; Mitrano et al., 2008). Palucha et al. (2004) found that 3-[(2methyl-1,3-thiazol-4-yl)ethynyl] pyridine (MTEP), an mGluR5 antagonist, dose-dependently inhibited morphine withdrawal symptoms induced by naloxone. DA and glutamate play critical roles in the induction of LTP in the NAc through the activation of D1 dopamine receptors and group I mGluRs (Schotanus and Chergui, 2008). It was reported that the number and function of group II mGluRs upregulated the formation of opioids withdrawal. Group II mGluRs (mGluR2 and mGluR3) were involved in the negative regulation in the brain reward circuit and the formation of conditional offensive responses in drug dependence and withdrawal. LY379268, the group II mGluRs agonist, reduced seeking behaviors induced by cocaine (Weiss and Baptista, 2003; Peters and Kalivas, 2006). Agonists of mGlu2/3 receptor prevent the reinstatement of drug-seeking and drug-taking behaviors after a period of abstinence (Markou, 2007). Agonists of group II mGluRs inhibited morphine withdrawal behaviors in 7-, 14- and 21-dayold rats (Zhu and Barr, 2004). The mGlu2/3 receptors in the NAc increased at days 1,3 , and 14 of morphine withdrawal (Modafferi et al., 2008). However, there were some conflicting reports. For instance, chronic application of cocaine decreased the function of group II mGluRs in the NAc (Robbe, 2002). Thus, the role of group II mGluRs in drug dependence was more complicated than previously thought (Kenny and Markou, 2004). Recently, it was reported that group III mGluR7 was implicated in many neurological and psychiatric diseases, including drug addiction. Systemic or intra-NAc administration of the mGluR7 allosteric agonist AMN082 dose-dependently lowered NAc extracellular
GABA and increased extracellular glutamate, and such effects were blocked by (R,S)-alpha-methylserine-O-phosphate (MSOP), a group III mGluR antagonist (Li et al., 2008). The mGluR8 mRNA levels were increased in the caudate putamen and NAc 1 day after the discontinuation of amphetamine treatments and sustained up to 21 days of withdrawal (Parelkar and Wang, 2008). However, the role of group III mGluRs in drug dependence is still not well investigated. Further investigation is required to fully understand the role of mGluRs in the pathological process of drug addiction.

\section{The signal transduction pathways of glutamate receptor in opioid addiction}

\subsection{Activation of NMDA-Ca ${ }^{2+}-\mathrm{NO}-\mathrm{cGMP}$ signal transduction pathway}

It was reported that the NMDA-Ca ${ }^{2+}-\mathrm{NO}-\mathrm{cGMP}$ pathway is involved in maintaining the excitability of neurons and plays an important role in opioid addiction and withdrawal (Elliot et al., 1995; Lizasoain et al., 1996; Noda et al., 1996; Vaupel et al., 1997). Nitric oxide synthase (NOS) inhibitor L-NAME as well as the soluble guanylate cyclase inhibitor methylene blue was found to significantly attenuate the naloxone-induced withdrawal contracture in guinea pig ileum. In addition, nitric oxide (NO) precursor and NO donors were able to reverse the effect of L-NAME. This effect also demonstrated that the competitive NMDA receptor antagonist AP-5 potently reduced the amplitude of naloxoneinduced contracture in the same model, an effect that was reversed by co-administration of the excitatory amino acid L-glutamate (Gabra et al., 2005). In this pathway, $\mathrm{Ca}^{2+}$ is the bridge between NMDA receptor and NO. Repeated application of opioid can activate NMDA receptors, subsequently activating the phosphatidylinositol pathway and increasing the release of $\mathrm{Ca}^{2+} \cdot \mathrm{Ca}^{2+}$ and calmodulin (CaM) combine to activate the $\mathrm{Ca}^{2+} / \mathrm{CaM}$ complex and NOS, resulting in the increase of NO. NO, which acts as a reverse regulator, can increase the concentration of second messenger cGMP by activating soluble guanylate cyclase. cGMP, an important intracellular second messenger, can directly regulate ion channels, affect the cGMP-dependent protein kinase, or change the cAMP content through phosphodiesterase, leading to withdrawal symptoms (Bredt and Snyder, 1992; Buccafusco et al., 1995; Kotecha and MacDonald, 2003). In addition, NO increases the release of glutamate by facilitating the presynaptic NMDA receptors to form a positive feedback loop, contributing to opioid dependence and withdrawal.

\subsection{Translocation of protein kinase $C$}

Some studies suggest that NMDA enhances $\mathrm{Ca}^{2+}$ influx through receptor-operated $\mathrm{Ca}^{2+}$ channels, increasing intracellular calcium concentration and thereby inducing the translocation of protein kinase $C(P K C)$ in guinea pig cerebral synaptoneurosomes and immature rat hippocampal slices (Etoh et al., 1991a,b). PKC translocated to cell membrane in superficial layer of spinal cord during morphine tolerance (Mayer et al., 1995). In addition, the development of morphine tolerance was related to the subunit of PKC, the subunits' concentration which was positively correlated to the development of morphine tolerance, and intrathecal injection of MK-801 that blocked the process (Mao et al., 1995). This evidence suggests that NMDA receptors were involved in the upregulation of PKC (Narita et al., 1995). Another study found that the activation of NMDA receptors inhibited the activity of opioid receptors and that the blockage of NMDA receptors inhibited the desensitization of opioid receptors (Cai et al., 1997). When activated by NMDA receptors, the transcription factor PKC translocated into cell nucleus, subsequently promoting the 
transcription of PKC and phosphorylate G-protein gene family. Opioid receptor desensitization occurs as a result (Fan et al., 1998).

\subsection{Activation of AC-CAMP-CREB pathway}

Some studies on the mechanism of morphine addiction suggested that repeated application of morphine induced change in cAMP system played important roles in morphine addiction (Noda et al., 2001). Chronic application of morphine increased the concentration of cAMP, cAMP-dependent protein kinase and cAMP response element binding (CREB) protein, thereby activating transcription and causing dependence and withdrawal symptoms (Nestler and Aghajanian, 1997). CREB is one of the members of CREB/ATF families and is also an important nuclear factor mediating the cAMP pathway and regulating gene transcription. Several studies showed that G-protein-CAMP-CREB pathway is the common mechanism of physical and psychological dependence. Guitart et al. (1992) found that acute application of morphine into locus coeruleus induced the decrease of CREB phosphorylation. On the other hand, long-term application of morphine induced the gradual increase of CREB and triggered a larger increase in the level of phosphorylation during naloxone-induced withdrawal (Hayward et al., 1990). Opioid-induced reinforcement and dependence of drugs by opioid receptors, and opioids receptors changed the cAMP signal transduction system by exciting G-protein or inhibiting $\mathrm{AC}$. In addition, opioids could activate $\mathrm{Ca}^{2+} / \mathrm{CaM}-$ dependent protein kinase (CaMK) and phosphorylate CREB. And the activation may be involved in the dependence triggered by the $\mathrm{Ca}^{2+}$-CaM-CaMK-CREB pathway (Wang et al., 1999). Glutamate receptors, especially NMDA receptors, can induce synaptic plasticity change of neurons by activating the AC-CAMP-CREB pathway, and are therefore involved in opioid dependence and withdrawal (Wang et al., 1999, 2007).

\subsection{Activation of MAPK pathway}

The subfamilies of mitogen-activated protein kinases (MAPKs) include extracellular signal-regulated kinases (ERK1 and ERK2), cJun N-terminal kinases (JNK1, JNK2 and JNK3), p38 MAPKs (p38 $\alpha$, p38 $\beta$, p38 $\gamma$ and p38 8 ), ERK3/4, and ERK5 (Davis, 2000; Chen et al., 2001; Chang and Karin, 2001; Johnson and Lapadat, 2002; Roux and Blenis, 2004). In recent years, the understanding of the role of the MAPK pathway in opioid-induced effects has evolved rapidly (Li and Chang, 1996; Chuang et al., 1997; Whistler and von Zastrow, 1999). Increasing evidence shows that cocaine or amphetamine and other substances of abuse can strongly activate the ERK pathway in the striatum or other forebrain structures through signaling mechanisms initiated by the activation of either DA or glutamate receptors or both (Berhow et al., 1996; Valjent et al., 2000, 2005; Freeman et al., 2001; Choe et al., 2002; Zhang et al., 2004; Jenab et al., 2005; Lu et al., 2005; Shi and McGinty, 2006; Tonini et al., 2006). All three subtypes of iGluRs and the three subgroups of mGluRs seem to consistently modulate the MAPK pathway in a stimulatory fashion (Wang et al., 2007). The iGluRs, particularly the NMDA receptor, may also activate the MAPK pathway through the $\mathrm{Ca}^{2+}$-sensitive Ras guanine nucleotide releasing factor, $\mathrm{Ca}^{2+}$-sensitive CaMKII and PI3K. Activation of the $\mathrm{Ca}^{2+}$-permeable NMDA receptors results in an increase in $\mathrm{Ca}^{2+}$ influx. The $\mathrm{Ca}^{2+}$ signals then activate several $\mathrm{Ca}^{2+}$-dependent kinases to increase ERK phosphorylation. After activation, ERK translocates to the nucleus and phosphorylate Elk-1 and CREB to facilitate gene expression (Valjent et al., 2000; Choe et al., 2002; Radwanska et al., 2005; Shi and McGinty, 2006). The alterations in the ERK-dependent transcriptional activity are then translated into molecular mechanisms underlying several types of persistent behavioral plasticity, such as rewarding response and behavioral sensitization induced by single or repeated psychostimulant administration. Blockage of the ERK pathway therefore abolishes these behavioral responses (Pierce et al., 1999; Valjent et al., 2000, 2005, 2006; Gerdjikov et al., 2004; Lu et al., 2005). AMPA receptors positively regulate MAPK/ERK phosphorylation (J.Q. Wang et al., 2004), and $\mathrm{Ca}^{2+}$-sensitive CaMKII and PI3K are the major kinases that form a pathway between AMPA receptors and ERK (Perkinton et al., 1999). Activation of KA receptors increased ERK phosphorylation in striatal neurons (Mao et al., 2004). This increase is also dependent on extracellular $\mathrm{Ca}^{2+}$ ions, but it is currently unclear whether other factors are involved in the process. The mGluRs can also activate MAPK pathway, mainly by the activation of tyrosine kinase receptor through $\mathrm{Ca}^{2+}$ non-sensitive channels (Wang et al., 2007).

\section{The interaction of glutamate and other neurotransmitters in opioid dependence}

\subsection{Glutamate and endogenous opioid peptide}

Endogenous opioid peptide is one of the most important neurotransmitters that are involved in opioid dependence. It has been demonstrated that $\mu$-opioid receptor is widely distributed in the VTA and the NAc. Opioids bind to endogenous $\mu$-opioid receptor in these regions, activate the reward circuit and induce the reward effect (McLean et al., 1986; Mansour et al., 1987; Johnson and North, 1992). It was reported that MK-801, a noncompetitive NMDA receptor antagonist, inhibited the analgesic tolerance induced by chronic morphine treatment. Pretreatment with MK-801 can eliminate the withdrawal symptoms in morphine-dependent mice (Trujillo and Akil, 1991). Studies have indicated that high concentration of opioid receptor agonists or antagonists can directly bind to NMDA receptors and share some characteristics of non-competitive agonists or antagonists of glutamate receptors (Yamakura et al., 1999). Enkephalin released by some neurons in the NAc can act on the $\mu$ - and $\delta$ - receptor and regulate the release of glutamate. MK-801 also can inhibit the downregulation of $\mu$-receptor in morphine-dependent rats (Koyuncuoglu et al., 1999). In addition, studies about the regulation of glutamate receptor on the opioid receptor have been reported. Competitive as well as non-competitive NMDA receptor antagonists enhance morphine's antinociceptive effect and prevent the development of morphine tolerance (Wong et al., 1996). All these studies suggest that there exists the interaction between glutamate receptors and opioid receptors which jointly participate in opiate dependence. The mechanism underlying the interaction is regarded to be postsynaptic. The glutamate receptor and opioid receptor can be co-expressed in the same neurons. Opioids can act on its receptor and induce the disinhibition of interneurons, which causes the release of glutamate and the activation of glutamate receptors. It is also presumed that opioids can act on their receptors, decrease the concentration of cAMP by inhibiting AC through $\mathrm{Gi}$ and Gs, and induce the activation of PKC. The activation of PKC can remove the blockage of $\mathrm{Mg}^{2+}$ on NMDA receptors and subsequently activates them (Tingley et al., 1997).

\subsection{Glutamate and dopamine}

It is well known that DA is the key neurotransmitter since most abused drugs increase its levels. Many pharmacotherapies have thus targeted this system (Nutt et al., 2003). The content of DA in the blood of withdrawal rats was significantly higher than that in normal rats. Microdialysis analysis showed that morphine could increase the release of DA (Di Chiara and Imperato, 1998). When drug-taking behaviors were initiated, dopaminergic and glutamatergic neurotransmission in the mesocorticolimbic system was 
activated (Tzschentke and Schmidt, 2003). Morphological studies showed that there existed axon-axon synapses of glutamate and DA in MPFC, the ventral striatum and the NAc, providing the morphological evidence for the interaction between glutamate and DA in the mesocorticolimbic dopaminergic pathway (Bouyer et al., 1984; Goldman-Rakic, 1999). Anatomical and electrophysiological evidence indicates that glutamate can be co-released with DA and induce long-term regulation on the plasticity (Lapish et al., 2006). Local application of glutamate can enhance the release of DA in the NAc (Youngren et al., 1993; Svensson et al., 1994). Electrical stimulation of basolateral amygdala (BLA) nucleus can increase the level of DA through its glutamatergic projections into the NAc and this effect can be blocked by perfusing glutamate receptor antagonists into the NAc (Floresco et al., 1998). Activation of iGluRs and mGluRs in the VTA increased the exploring behaviors and the levels of DA in the NAc and the MPFC (Suaud-Chagny et al., 1992; Swanson and Kalivas, 2000). These results suggest that glutamate can facilitate the release of DA by its receptors and can be involved in drug dependence and withdrawal processes. Application of glutamate receptor antagonists attenuated most of the withdrawal symptoms. In the addicted state, different dopaminergic projections may be altered differentially, resulting in an altered DA-glutamate interaction that ultimately leads to aberrant control over behaviors and compulsive drug-taking behaviors (Tzschentke and Schmidt, 2003). DA and glutamate interact in a complex way. Glutamatergic input to the VTA increases the activity of dopaminergic cells and enhances DA release in the NAc (Tzschentke and Schmidt, 2000; Tzschentke, 2001). At the level of the NAc, glutamate also facilitates dopaminergic transmission, presumably by presynaptically influencing DA release (Blaha et al., 1997; Floresco et al., 1998). The DA releasing effect of glutamate in the NAc may be predominantly mediated by AMPA (rather than NMDA) receptors (Youngren et al., 1993). However, some studies found that application of glutamate receptor antagonists increased the movement enhancement in withdrawal rats (Narayanan et al., 1995; Kretschmer, 1999; Ungless et al., 2001). Consistent with the above, studies also found that microinjection of glutamate receptor antagonist MK801 or DNQX into the VTA attenuated most of the morphine withdrawal symptoms, except the wall-climbing behavior (H.L. Wang et al., 2004; Wang et al., 2005). The reason for these phenomena is that there exist some GABAergic neurons in the VTA and the NAc, which can inhibit the release of DA. Glutamate receptor antagonists can increase the release of DA by inhibiting GABA neurons. DA also affects glutamatergic transmission. For instance, DA modulates glutamatergic signals in the NAc originating from the amygdala and hippocampus in a manner consistent with the concept of a gating mechanism or input selection (Floresco et al., 2001; Tzschentke and Schmidt, 2003).

\subsection{Glutamate and $\gamma$-aminobutyric acid}

GABA is an inhibitory neurotransmitter in the central nervous system. It is involved in opioid dependence and can inhibit withdrawal symptoms induced by naloxone (Zarrindast and Mousa-Ahmadi, 1999). The release of GABA and the amplitude and frequency of inhibitory postsynaptic potentials of GABAergic neurons increased in morphine withdrawal rats. The activation of opioid receptors on VTA interneurons inhibited the activities of GABA neurons and reduced the release of GABA, which caused the disinhibition of the DA neurons in the VTA and the release of DA in the NAc, contributing to opioid withdrawal (Bonci and Williams, 1997). Single or chronic exposure to morphine inhibited the release of GABA in the NAc. This effect persisted even after the stop of morphine. The inhibition of baclofen, a GABA agonist, on morphine withdrawal symptoms suggested the involvement of GABA in morphine dependence and withdrawal (Acquas and Di Chiara, 1992). The reward effect in mice and physical dependence induced by naloxone was attenuated when GABA transporters were over expressed (Schoffelmeer et al., 2001; Hu et al., 2003). Application of $\mathrm{GABA}_{\mathrm{B}}$ receptor antagonist 2-OH-saclofen alone significantly increased the extracellular concentration of DA, suggesting that the DA neurons in the VTA were inhibited tonically by endogenous GABA (Xi and Stein, 2002a). Microinjection of baclofen into the VTA activated $G A B A_{B}$ receptors and blocked self-administration behaviors induced by heroin, DA release in the NAc (Xi and Stein, 1998, 1999) and morphine-induced CPP (Tsuji et al., 1996). It can be presumed that $\mathrm{GABA}_{\mathrm{B}}$ receptors in the VTA play a key role in opioid dependence. Anatomical studies show that NMDA and non-NMDA receptors are located in the postsynaptic GABAergic projection neurons. Glutamatergic projections from the MPFC connected to the GABAergic spinous neurons with excitatory synapses (Xi and Stein, 2002a). The balance between excitatory amino acid and the inhibitory amino acid determines the state and response of neurons. These results suggest that glutamate activate GABAergic neurons in the NAc by NMDA or AMPA receptor. The activation of GABAergic neurons increases the release of GABA and inhibit the activities of DA in the VTA, and finally contribute to the opioid addiction.

\subsection{Glutamate and substance $P$}

Substance P (SP) is an important sensory neuropeptide widely distributed in the central and peripheral nervous system and peripheral tissues. Morphological studies show that nerve fibers containing SP connect to DA neurons with synapses in the VTA. There also exist medium-density bradykinin immune positive fibers in the NAc (Otsuka and Yoshioka, 1993). It has been reported that SP in the NAc binding with NK-1 receptor could indirectly inhibit excitatory synaptic transmission by increasing extracellular level of DA and adenosine (Kombian et al., 2003). Recent studies have shown that knockout of preprotachykinin A (PPT-A) can reduce the number of $\delta$-opioid receptors inserted into the surface. The knockout of this molecule also removed spinal analgesia and the morphine tolerance mediated by $\delta$-opioid receptor, suggesting that there may exist a direct link between tachykinin and opioid system through interacting with tachykinin/ $\delta$-opioid receptors (Guan et al., 2005). Knockout of NK-1 receptors in mice decreased CPP score induced by morphine and influenced reward effects of morphine (Gadd et al., 2003). Behavioral studies have shown that SP (1-7) and SP (1-11) attenuate opioid reward and a variety of physical withdrawal symptoms, and that SP (1-7) can significantly reduce the D2 dopamine receptor transcription in the NAc and mPFC (Zhou et al., 2003). Microperfusion of SP N-terminal fragment into the VTA increased the content of DA and the DA metabolism in the NAc in morphine withdrawal mice, suggesting that N-terminal peptides of SP could attenuate the morphine withdrawal symptoms by increasing DA release and its metabolism in the NAc. This mechanism may be related to glutamatergic transmission (Zhou and Nyberg, 2002). Morphological studies have demonstrated that SP and other neurotransmitters such as Glu and DA are co-localizated in mesocorticolimbic dopaminergic pathway, indicating that SP may interact with other neurotransmitters and that it is involved in drug dependence. Some studies have shown that SP can enhance the effects of glutamate in the spinal dorsal horn and induce the wind-up phenomenon, which is regarded as the mechanism underlying the central sensitization (Dougherty et al., 1993). Local injection of SP enhanced the nociceptive behavioral response in spinal cord (Carlton et al., 1998) and increased the discharge of primary afferent fibers induced by glutamate (Zhang et al., 2006). Administration of monosodium glutamate could increase the expression of PPT-A mRNA in cerebral cortex, amygdala, etc. (Xu et al., 2007). All these results 
indicate that there exists interaction between glutamate and SP, but their exact roles in opioid dependence has yet to be studied.

\section{Conclusion}

Opioid addiction is a chronically relapsing disorder and the neural network involved is associated with several brain nuclei and neurotransmitters/neuropeptides. There is evidence that the mesocorticolimbic dopaminergic regions, especially the VTA and $\mathrm{NAc}$, are the key regions of opioid psychological dependence. Historically, research into the neurobiological substances that underlie the drug addiction has focused on the DA system. In the latest 5 years, more attention has focused on the role of glutamate and its receptors in mesocorticolimbic dopaminergic regions in opioid addiction. As a primary excitatory neurotransmitter in the brain, glutamate can be responsible for development of addictive behaviors by binding with its iGluRs and mGluRs and involved in the opioid addiction. The role of iGluRs is well investigated and antagonists of both NMDA and AMPA receptors attenuate the withdrawal syndrome of opioid dependence. The role of mGluRs is still unclear and needs to be further studied. The activations of several signal transduction pathways including NMDA- $\mathrm{Ca}^{2+}-\mathrm{NO}-$ cGMP pathway, AC-cAMP-CREB pathway and MAPK pathway are involved in the plastic changes induced by glutamate. In addition, glutamate receptors and other neurotransmitter/neuropeptide receptors such as opioids, DA, GABA and SP coexisted in the mesocorticolimbic dopaminergic regions and interact with each other in opioid addiction. In summary, glutamate and its receptors are important in opioid addiction, and these findings have increased our understanding of the neuropathological processes associated with opioid addiction and have provided new targets for pharmacological approach to the treatment of opioid addiction.

\section{Acknowledgements}

The project was supported by the National Natural Science Foundation of China (No. 30600219 and No. 30772705), the Special Research Fund for the Doctoral Program of High Education (No. 20070698101) and Research Fund of Medical College of Chinese People's Armed Police Forces (WY2006-13).

\section{References}

Acquas, E., Di Chiara, G., 1992. Depression of mesolimbic dopamine transmission and sensitization to morphine during opiate abstinence. J. Neurochem. 58, 1620-1625.

American Psychiatric Association, 1994. Diagnostic and Statistical Manual of Mental Disorders, 4th ed. American Psychiatric Press, Washington, DC.

Berhow, M.T., Hiroi, N., Nestler, E.J., 1996. Regulation of ERK (extracellular signal regulated kinase), part of the neurotrophin signal transduction cascade, in the rat mesolimbic dopamine system by chronic exposure to morphine or cocaine. J. Neurosci. 16, 4707-4715.

Bisaga, A., Comer, S.D., Ward, A.S., 2001. The NMDA antagonist memantine attenuates the expression of opioid physical dependence in humans. Psychopharmacology $157,1-10$

Bjorklund, A., Dunnett, S.B., 2007. Dopamine neuron systems in the brain: an update. Trends Neurosci. 30, 194-202.

Blaha, C.D., Yang, C.R., Floresco, S.B., Barr, A.M., Phillips, A.G., 1997. Stimulation of the ventral subiculum of the hippocampus evokes glutamate receptormediated changes in dopamine efflux in the rat nucleus accumbens. Eur. J. Neurosci. 9, 902-911.

Bonci, A., Williams, J.T., 1997. Increased probability of GABA release during withdrawal from morphine. J. Neurosci. 17, 796-803.

Bouyer, J.J., Park, D.H., Joh, T.H., Pickel, V.M., 1984. Chemical and structural analysis of the relation between cortical inputs and tyrosine hydroxylase-containing terminals in rat neostriatum. Brain Res. 302, 267-275.

Bredt, D.S., Snyder, S.H., 1992. Nitric oxide, a novel neuronal messenger. Neuron 8 , $3-11$.

Bristow, L.J., Hogg, J.E., Hutson, P.H., 1997. Competitive and glycine/NMDA receptor antagonists attenuate withdrawal-induced behaviours and increased hippocampal acetylcholine efflux in morphine-dependent rats. Neuropharmacology 36, 241-250.
Buccafusco, J.J., Terry Jr., A.V., Shuster, L., 1995. Spinal NMDA receptor-nitric oxide mediation of the expression of morphine withdrawal symptoms in the rat. Brain Res. 679, 189-199.

Cai, Y.C., Ma, L., Fan, G.H., Zhao, J., Jiang, L.Z., Pei, G., 1997. Activation of N-methyl-Daspartate receptor attenuates acute responsiveness of $\delta$-opioid receptors. Mol. Pharmacol. 51, 583-587.

Carlton, S.M., Zhou, S., Coggeshall, R.E., 1998. Evidence for the interaction of glutamate and NK1 receptors in the periphery. Brain Res. 790, 160-169.

Carr, D.B., Sesack, S.R., 2000. Projections from the rat prefrontal cortex to the ventral tegmental area: target specificity in the synaptic associations with mesoaccumbens and mesocortical neurons. J. Neurosci. 20, 3864-3873.

Chang, L., Karin, M., 2001. Mammalian MAP kinase signalling cascades. Nature 410 37-40.

Chang, J.Y., Zhang, L.L., Janak, P.H., Woodward, D.J., 1997. Neuronal responses in prefrontal cortex and nucleus accumbens during heroin self-administration in freely moving rats. Brain Res. 754, 12-20.

Chen, Z., Gibson, T.B., Robinson, F., Silvestro, L., Pearson, G., Xu, B.E., Wright, A., Vanderbilt, C., Cobb, M.H., 2001. MAP kinases. Chem. Rev. 101, 2449-2476.

Chergui, K., Charlety, P.J., Akaoka, H., Saunier, C.F., Brunet, J.L., Buda, M., Svensson, T.H., Chouvet, G., 1993. Tonic activation of NMDA receptors causes spontaneous burst discharge of rat midbrain dopamine neurons in vivo. Eur. J. Neurosci. 5, 137-144.

Choe, E.S., Chung, K.T., Mao, L., Wang, J.Q., 2002. Amphetamine increases phosphorylation of extracellular signal regulated kinase and transcription factors in the rat striatum via group I metabotropic glutamate receptors. Neuropsychopharmacology 27, 565-575.

Chuang, L.F., Killam, K.F., Chuang, R.Y., 1997. Induction and activation of mitogenactivated protein kinases of human lymphocytes as one of the signaling pathways of the immunomodulatory effects of morphine sulfate. J. Biol. Chem. 272, 26815-26817.

Chuhma, N., Zhang, H., Masson, J., Zhuang, X., Sulzer, D., Hen, R., Rayport, S., 2004 Dopamine neurons mediate a fast excitatory signal via their glutamatergic synapses. J. Neurosci. 24, 972-981.

Conn, P.J., Desai, M.A., 1991. Pharmacology and physiology of metabotropic glutamate receptors in mammalian central nervous system. Drug Dev. Res. 24, $207-$ 229.

Conn, P.J., Pin, J.P., 1997. Pharmacology and functions of metabotropic glutamate receptors. Annu. Rev. Pharmacol. Toxicol. 37, 205-237.

Cotman, C.W., Monaghan, D.T., Ottersen, O.P., Storm-Mathisen, J., 1987. Anatomical organization of excitatory amino acid receptors and their pathway. Trends Neurosci. 10, 273-280.

Coutinho, V., Knopfel, T., 2002. Metabotropic glutamate receptors: electrical and chemical signaling properties. Neuroscientist 8, 551-561.

Dackis, C.A., Gold, M.S., 1985. New concepts in cocaine addiction: the dopamine depletion hypothesis. Neurosci. Biobehav. Rev. 9, 469-477.

Davis, R.J., 2000. Signal transduction by the JNK group of MAP kinases. Cell 103 239-252.

De Vries, T.J., Shippenberg, T.S., 2002. Neural system underlying opiate addiction. J. Neurosci. 22, 3321-3325

Di Chiara, Imperato, G.A., 1998. Drug abused by human preferentially increase synaptic dopamine concentrations in the mesolimbic system of freely moving rats. Proc. Natl. Acad. Sci. U.S.A. 85, 5274-5278.

Di Chiara, G., 1995. The role of dopamine in drug abuse viewed from the perspective of its role in motivation. Drug Alcohol Depend. 38, 95-137.

Di Ciano, P., Cardinal, R.N., Cowell, R.A., Little, S.J., Eceritt, B.J., 2001. Differential involvement of NMDA, AMPA/kainate, and dopamine receptors in the nucleus accumbens core in the acquisition and performance of Pavlovian approach behavior. J. Neurosci. 21, 9471-9477.

Dingledine, R., Borges, K., Bowie, D., Traynelis, S.F., 1999. The glutamate receptor ion channels. Pharmacol. Rev. 51, 7-62.

Dougherty, P.M., Palecek, J., Zorn, S., Willis, W.D., 1993. Combined application of excitatory amino acids and substance $\mathrm{P}$ produces long-lasting changes in responses of primate spinothalamic tract neurons. Brain Res. Brain Res. Rev. $18,227-246$

Elliot, K., Kest, B., Man, A., Kao, B., Inturissi, C.E., 1995. N-methyl-D-aspartate (NMDA) receptors, mu and kappa opioid tolerance, and perspectives on new analgesic drug development. Neuropsychopharmacology 13, 347-356.

Etoh, S., Baba, A., Iwata, H., 1991a. NMDA induces protein kinase $\mathrm{C}$ translocation in guinea pig cerebral synaptoneurosomes. Jpn. J. Pharmacol. 56, 287-296.

Etoh, S., Baba, A., Iwata, H., 1991b. NMDA induces protein kinase C translocation in hippocampal slices of immature rat brain. Neurosci. Lett. 126, 119-122.

Everitt, B.J., Dickinson, A., Robbins, T.W., 2001. The neuropsychological basis of addictive behaviour. Brain Res. Rev. 36, 129-138.

Fallon, J.H., Moore, R.Y., 1978. Catecholamine innervation of the basal forebrain. IV Topography of the dopamine projection to the basal forebrain and neostriatum. J. Comp. Neurol. 180, 545-580.

Fan, G.H., Zhao, J., Wu, Y.L., Lou, L.G., Zhang, Z., Jing, Q., Ma, L., Pei, G., 1998. Nmethyl-D-aspartate attenuates opioid receptor-mediated $G$ protein activation and this process involves protein kinase C. Mol. Pharmacol. 53, 684-690.

Fields, H.L., Hjelmstad, G.O., Margolis, E.B., Nicola, S.M., 2007. Ventral tegmental area neurons in learned appetitive behavior and positive reinforcement. Annu. Rev. Neurosci. 30, 289-316.

Fitzgerald, L.W., Ortiz, J., Hamedani, A.G., Nestler, E.J., 1996. Drugs of abuse and stress increase the expression of GluR1 and NMDAR1 glutamate receptor subunits in the rat ventral tegmental area: common adaptations among cross-sensitizing agents. J. Neurosci. 16, 274-282. 
Floresco, S.B., Blaha, C.D., Yang, C.R., Phillips, A.G., 2001. Dopamine D1 and NMDA receptors mediate potentiation of basolateral amygdala-evoked firing of nucleus accumbens neurons. J. Neurosci. 21, 6370-6376.

Floresco, S.B., Yang, C.R., Phillips, A.G., Blaha, C.D., 1998. Basolateral amygdala stimulation evokes glutamate receptor-dependent dopamine efflux in the nucleus accumbens of the anaesthetized rat. Eur. J. Neurosci. 10, 1241-1251.

Fonnum, F., 1984. Glutamate: a neurotransmitter in mammalian brain. J. Neurochem. 42, 1-11.

Freeman, W.F., Brebner, K., Lynch, W.J., Robertson, D.J., Roberts, D.C.S., Vrana, K.E., 2001. Cocaine-responsive gene expression changes in rat hippocampus. Neuroscience $108,371-380$.

Fundytus, M.E., Coderre, T.J., 1994. Effect of activity at metabotropic, as well as ionotropic (NMDA), glutamate receptors on morphine dependence. Br. J. Pharmacol. 113, 1215-1220.

Gabra, B.H., Afify, E.A., Daabees, T.T., Zeit-Har, M.S.A., 2005. The role of the NO/ NMDA pathways in the development of morphine withdrawal induced by naloxone in vitro. Pharmacol. Res. 51, 319-327.

Gadd, C.A., Murtra, P., Felipe, C.D., Hunt, S.P., 2003. Neurokinin-1 receptor-expressing neurons in the amygdala modulate morphine reward and anxiety behaviors in the mouse. J. Neurosci. 23, 8271-8280.

Gass, J.T., Olive, M.F., 2008. Glutamatergic substrates of drug addiction and alcoholism. Biochem. Pharmacol. 75, 218-265.

Geisler, S., Derst, C., Veh, R.W., Zahm, D.S., 2007. Glutamatergic afferents of the ventral tegmental area in the rat. J. Neurosci. 27, 5730-5743.

Gerdjikov, T.V., Ross, G.M., Beninger, R.J., 2004. Place preference induced by nucleus accumbens amphetamine is impaired by antagonists of ERK or p38 MAP kinases in rats. Behav. Neurosci. 118, 740-750.

Glass, M.J., Lane, D.A., Colago, E.E.O., Chan, J., Schlussman, S.D., Zhou, Y., Kreek, M.J. Pickel, V.M., 2008. Chronic administration of morphine is associated with decrease in surface AMPA GluR1 receptor subunit in dopamine D1 receptor expressing neurons in the shell and non-D1 receptor expressing neurons in the core of the rat nucleus accumbens. Exp. Neurol. 210, 750-761.

Goldman-Rakic, P.S., 1999. The physiological approach: functional architecture of working memory and disordered cognition in schizophrenia. Biol. Psychiatry 46, 650-661

Goldstein, R.A., Volkow, N.D., 2002. Drug addiction and its underlying neurobiological basis: neuroimaging evidence for the involvement of the frontal cortex. Am. J. Psychiatry 159, 1642-1652.

Grace, A.A., Bunney, B.S., 1984. The control of firing pattern in nigral dopamine neurons: single spike firing. J. Neurosci. 4, 2866-2876.

Grant, S., London, E.D., Newlin, D.B., 1996. Activation of memory circuits during cueelicited cocaine craving. PNAS 93, 12040-12045.

Groenewegen, H.J., Vermeulen-Van der Zee, E., te Kortschot, A., Witter, M.P., 1987. Organization of the projections from the subiculum to the ventral striatum in the rat. A study using anterograde transport of Phaseolus vulgaris-leucoagglutinin. Neuroscience 23, 103-112.

Groenewegen, H.J., Wright, C.I., Beijer, A.V., Voorn, P., 1999. Convergence and segregation of ventral striatal inputs and outputs. Ann. N.Y. Acad. Sci. 877 49-63.

Guan, J.S., Xu, Z.Z., Gao, H., He, S.Q., Ma, G.Q., Sun, T., Wang, L.H., Zhang, Z.N., Lena, I. Kitchen, I., Elde, R., Zimmer, A., He, C., Pei, G., Bao, L., Zhang, X., 2005. Interaction with vesicle luminal protachykinin regulates surface expression of delta-opioid receptors and opioid analgesia. Cell 122, 619-631.

Gudehithlu, K.P., Reddy, P.L., Bhargava, H.N., 1994. Effect of morphine tolerance and abstinence on the binding of $\left[{ }^{3} \mathrm{H}\right] \mathrm{MK}-801$ to brain regions and spinal cord of the rat. Brain Res. 639, 269-274.

Guitart, X., Thompson, M.A., Mirante, C.K., Greenberg, M.E., Nestler, E.J., 1992 Regulation of cyclic AMP response element-binding protein (CREB) phosphorylation by acute and chronic morphine in the rat locus coeruleus. J. Neurochem. 58, 1168-1171.

Harris, G.C., Aston-Jones, G., 1994. Involvement of D2 dopamine receptors in the nucleus accumbens in the opiate withdrawal syndrome. Nature 371,155 157.

Hayward, M.D., Duman, R.S., Nestler, E.J., 1990. Induction of the c-fos protooncogene during opiate withdrawal in the locus coeruleus and other regions of rats brain. Brain Res. 525, 256-266.

Headley, P.M., Grillner, S., 1990. Excitatory amino acids and synaptic transmission: the evidence for a physiological function. Trends Pharmacol Sci. 11, 205-211.

Heimer, L., Alheid, G.F., de Olmos, J.S., Groenewegen, H.J., Haber, S.N., Harlan, R.E., Zahm, D.S., 1997. The accumbens: beyond the coreshell dichotomy. J. Neuropsychiatry Clin. Neurosci. 9, 354-381.

Hermans, E., Challiss, R.A., 2001. Structural, signalling and regulatory properties of the group I metabotropic glutamate receptors: prototypic family C G-proteincoupled receptors. Biochem. J. 359, 465-484

Herz, A., Shippenberg, T.S., Bals-kubik, R., Spanagel, R., 1992. Opiate addiction: pharmacologic and biochemical aspects. Arzeimittelforschung 42, 256-259.

Hu, J.H., Yang, N., Ma, Y.H., 2003. Decrease of morphine-induced reward effects and withdrawal symptoms in mice overexpressing gamma-aminobutyric acid transporter I. J. Neurosci. Res. 74, 614-621.

Ivanov, A., Aston-Jones, G., 2001. Local opiate withdrawal in locus coeruleus neurons in vitro. Neurophysiology 85, 2388-2397.

Jenab, S., Festa, E.D., Nazarian, A., Wu, H.B., Sun, W.L., Hazim, R., Russo, S.J., Quinones-Jenab, V., 2005. Cocaine induction of ERK proteins in dorsal striatum of Fischer rats. Mol. Brain Res. 142, 134-138.

Jingami, H., Nakanishi, S., Morikawa, K., 2003. Structure of the metabotropic glutamate receptor. Curr. Opin. Neurobiol. 13, 271-278.
Johnson, G.L., Lapadat, R., 2002. Mitogen-activated protein kinase pathways mediated by ERK, JNK, and p38 protein kinases. Science 298, 1911-1912.

Johnson, S.W., North, R.A., 1992. Opioids excite dopamine neurons by hyperpolarization of local interneurons. J. Neurosci. 12, 483-488.

Jongen-Relo, A.L., Groenewegen, H.J., Voorn, P., 1993. Evidence for a multi-compartmental histochemical organization of the nucleus accumbens in the rat. J. Comp. Neurol. 337, 267-276.

Jongen-Relo, A.L., Voorn, P., Groenewegen, H.J., 1994. Immunohistochemical characterization of the shell and core territories of the nucleus accumbens in the rat. Eur. J. Neurosci. 6, 1255-1264.

Kalivas, P.W., Duffy, P., 1998. Repeated cocaine administration alters extracellular glutamate in the ventral tegmental area. J. Neurochem. 70, 1497-1502.

Kalivas, P.W., LaLumiere, R.T., Knackstedt, L., Shen, H., 2009. Glutamate transmission in addiction. Neuropharmacolgy 56, 169-173.

Kalivas, P.W., O'Brien, C., 2008. Drug addiction as a pathology of staged neuroplasticity. Neuropsychopharmacology 33, 166-180.

Kalivas, P.W., Volkow, N.D., 2007. The neural basis of addiction: a pathology of motivation and choice. Focus 5, 208-219.

Kalivas, P.W., 2004. Glutamate system in cocaine addiction. Curr. Opin. Pharmacol. $4,23-29$.

Kalivas, P.W., 1993. Neurotransmitter regulation of dopamine neurons in the ventral tegmental area. Brain Res. Rev. 18, 75-113.

Kelley, A.E., Domesick, V.B., Nauta, W.J.H., 1982. The amygdalostriatal projection in the rat-an anatomical study by anterograde and retrograde tracing methods. Neuroscience 7, 615-630.

Kenny, P.J., Markou, A., 2004. The ups and downs of addiction: role of metabotropic glutamate receptors. Trends Pharmacol. Sci. 25, 265-272.

Kiyatkin, E.A., Rebee, G.V., 2001. Impulse activity of ventral tegmental area neurons during heroin self-administration in rats. Neuroscience 102, 565-580.

Kombian, S.B., Ananthalakshmi, K.V., Parvathy, S.S., Matowe, W.C., 2003. Dopamine and adenosine mediate substance P-induced depression of evoked IPSCs in the rat nucleus accumbens in vitro. Eur. J. Neurosci. 18, 303-311.

Koob, G.F., Ahmed, S.H., Boutrel, H., Chen, S.A., Kenny, P.J., Markou, A., O'Dell, L.E., Parsons, L.H., Sanna, P.P., 2004. Neurobiological mechanisms in the transition from drug use to drug dependence. Neurosci. Biobehav. Rev. 27, 739-749.

Koob, G.F., Nestler, E.J., 1997. The neurobiology of drug addiction. J. Neuropsychiatry Clin. Neurosci. 9, 482-497.

Koob, G.F., Sanna, P.P., Bloom, F.E., 1998. Neuroscience of addiction. Neuron 21, 467-476.

Koob, G.F., 1992. Drug of abuse: anatomy, pharmacology and function of reward pathways. Trends Pharmacol. Sci. 13, 177-184.

Koob, G.F., 2003. Neuroadaptive mechanisms of addiction: studies on the extended amygdala. Eur. Neuropsychopharmacol. 13, 442-452.

Kotecha, S.A., MacDonald, J.F., 2003. Signaling molecules and receptor transduction cascades that regulate NMDA receptor-mediated synaptic transmission. Int. Rev. Neurobiol. 54, 51-106.

Koyuncuoglu, H., Nurten, A., Yamanturk, P., Nurten, R., 1999. The importance of the number of NMDA receptors in the development of supersensitivity or tolerance to and dependence on morphine. Pharmacol. Res. 39, 311-319.

Kretschmer, B.D., 1999. Modulation of the mesolimbic dopamine system by glutamate: role of NMDA receptor. J. Neurochem. 73, 839-848.

Lapish, C.C., Seamans, J.K., Chandler, L.J., 2006. Glutamate-dopamine cotransmission and reward processing in addiction. Alcohol. Clin. Exp. Res. 30, 1451-1465.

Lavin, A., Nogueira, L., Lapish, C.C., Wightman, R.M., Phillips, P.E., Seamans, J.K., 2005. Mesocortical dopamine neurons operate in distinct temporal domains using multimodal signaling. J. Neurosci. 25, 5013-5023.

Li, L.Y., Chang, K.J., 1996. The stimulatory effect of opioids on mitogen-activated protein kinase in Chinese hamster ovary cells transfected to express mu-opioid receptors. Mol. Pharmacol. 50, 599-602.

Li, X., Gardner, E.L., Xi, Z.X., 2008. The metabotropic glutamate receptor 7 (mGluR7) allosteric agonist AMN082 modulates nucleus accumbens GABA and glutamate, but not dopamine, in rats. Neuropharmacology 54, 542-551.

Lizasoain, I., Leza, J.C., Cuellar, B., Moro, M.A., Lorenzo, P., 1996. Inhibition of morphine withdrawal by lamotrigine: involvement of nitric oxide. Eur. J. Pharmacol. 299, 41-45.

Lu, L., Hope, B.T., Dempsey, J., Liu, S.Y., Bossert, J.M., Shaham, Y., 2005. Central amygdale ERK signaling pathway is critical to incubation of cocaine craving. Nat. Neurosci. 8, 212-219.

Madden, D.R., 2002. The structure and function of glutamate receptor ion channels. Nat. Rev. Neurosci. 3, 91-101.

Manning, B.H., Mao, J., Frenk, H., Price, D.D., Mayer, D.J., 1996. Continuous coadministration of dextromethorphan or MK-801 with morphine: attenuation of morphine dependence and naloxone-reversible attenuation of morphine tolerance. Pain 67, 79-88.

Mansour, A., Khachaturian, H., Lewis, M.E., Akil, H., Watson, S.J., 1987. Autoradiographic differentiation of $\mathrm{m}, \mathrm{d}$, and $\mathrm{k}$ opioid receptors in the rat forebrain and midbrain. J. Neurosci. 7, 2445-2464

Manzanares, J., Corchero, J., Romero, J., Fernandez-Ruiz, J.J., Ramos, J.A., Fuentes, J.A., 1999. Pharmacological and biochemical interactions between opioids and cannabinoids. Trends Pharmacol. Sci. 20, 287-294.

Mao, J., Price, D.D., Phillips, L.L., Lu, J., Mayer, D.J., 1995. Increases in protein kinase C gamma immunoreactivity in the spinal cord of rats associated with tolerance to the analgesic effects of morphine. Brain Res. 677, 257-267.

Mao, L., Tang, Q., Samdani, S., Liu, Z., Wang, J.Q., 2004. Regulation of MAPK/ERK phosphorylation via ionotropic glutamate receptors in cultured rat striatal neurons. Eur. J. Neurosci. 19, 1207-1216. 
Margolis, E.B., Lock, H., Hjelmstad, G.O., Fields, H.L., 2006. The ventral tegmental area revisited: is there an electrophysiological marker for dopaminergic neurons? J. Physiol. 577, 907-924.

Markou, A., 2007. The role of metabotropic glutamate receptors in drug reward, motivation and dependence. Drug News Perspect. 20, 103-108.

Mayer, D.J., Mao, J., Price, D.D., 1995. The development of morphine tolerance and dependence is associated with translocation of protein kinase C. Pain 61, 365374.

McLaughlin, J., See, R.E., 2003. Selective inactivation of the dorsomedial prefrontal cortex and the basolateral amygdala attenuates conditioned-cued reinstatement of extinguished cocaine-seeking behavior in rats. Psychopharmacology (Berl) 168, 57-65.

McLean, S., Rothman, R.B., Herkenham, M., 1986. Autoradiographic localization of $\mathrm{m}$ - and d-opiate receptors in the forebrain of the rat. Brain Res. 378, 49-60.

Meredith, G.E., Pattiselanno, A., Groenewegen, H.J., Haber, S.N., 1996. Shell and core in monkey and human nucleus accumbens identified with antibodies to calbindin-D28k. J. Comp. Neurol. 365, 628-639.

Miller, R.J., 1994. G-protein linked glutamate receptor. Semin. Neurosci. 6, 105-115.

Mitrano, D.A., Smith, Y., 2007. Comparative analysis of the subcellular and subsynaptic localization of mGluR1a and mGluR5 metabotropic glutamate receptors in the shell and core of the nucleus accumbens in rat and monkey. J. Comp. Neurol. 500, 788-806.

Mitrano, D.A., Arnold, C., Smith, Y., 2008. Subcellular and subsynaptic localization of group I metabotropic glutamate receptors in the nucleus accumbens of cocainetreated rats. Neuroscience 154, 653-666.

Modafferi, A.M., Diana, M., Nicoletti, F., Scaccianoce, S., 2008. Morphine withdrawal increases metabotropic glutamate $2 / 3$ receptors expression in nucleus accumbens. Neuroreport 19, 911-914.

Monaghan, D.T., Bridges, R.J., Cotman, C.W., 1989. The excitatory amino acid receptors: their classes, pharmacology, and distinct properties in the function of the central nervous system. Annu. Rev. Pharmacol. Toxicol. 29, 365-402.

Monyer, H., Spregel, R., Schoepfer, R., Herb, A., Hihuchi, M., Lomeli, H., Burnashev, N., Sakmann, B., Seeburg, P.H., 1992. Heteromeric NMDA receptors: molecular and functional distinction of subtypes. Science 256, 1217-1221.

Mudo, G., Trovato-Salinaro, A., Caniglia, G., Cheng, Q., Condorelli, D.F., 2007. Cellular localization of mGluR3 and mGluR5 mRNAs in normal and injured rat brain. Brain Res. 1149, 1-13.

Murase, S., Grenhoff, J., Chouvet, G., Gonon, F.G., Svensson, T.H., 1993. Prefrontal cortex regulates burst firing and transmitter release in rat mesolimbic dopamine neurons studied in vivo. Neurosci. Lett. 157, 53-56.

Myers, S.J., Dingledine, R., Borges, K., 1999. Genetic regulation of glutamate receptor ion channels. Annu. Rev. Pharmacol. Toxicol. 39, 221-241.

Nakanishi, S., 1992. Molecular diversity of glutamate receptors and implications for brain functions. Science 258, 597-603.

Narayanan, S., Willam, D., Dalia, A., 1995. Role of dopaminergic mechanisms in the stimulatory effects of MK-801 injected into the ventral tegmental area and the nucleus accumbens. Pharmcol. Biochem. Behav. 54, 565-573.

Narita, M., Narita, M., Mizoguchi, H., Tseng, L.F., 1995. Inhibition of protein kinase C, but not of protein kinase A, blocks the development of acute antinociceptive tolerance to an intrathecally administered mu-opioid receptor agonist in the mouse. Eur. J. Pharmacol. 280, R1-R3.

Nestler, E.J., Aghajanian, G.K., 1997. Molecular and cellular basis of addiction. Science 278, 58-63.

Nestler, E.J., Hyman, S.E., Malenka, R.C., 2001. Molecular Neuropharmacology: A Foundation for Clinical Neuroscience. McGraw-Hill, New York.

Noda, Y., Mamiya, T., Nabeshima, T., 2001. The mechanisms of morphine dependence and it's withdrawal syndrome: study in mutant mice. Nippon Yakurigaku Zasshi 117, 21-26.

Noda, Y., Yamada, K., Komori, Y., Sugihara, H., Furukawa, H., Nabeshima, T., 1996. Role of nitric oxide in the development of tolerance and sensitization to behavioural effects of phencyclidine in mice. Br. J. Pharmacol. 117, 1579-1585.

Nutt, D., Lingford-Hughes, A., Daglish, M., 2003. Future directions in substance dependence research. J. Neural Transm. Suppl. 64, 95-103.

O'Donnell, P., Grace, A.A., 1993. Physiological and morphological properties of accumbens core and shell neurons recorded in vitro. Synapse 13, 135-160.

Otsuka, M., Yoshioka, K., 1993. Neurotransmitter functions of mammalian tachykinins. Physiol. Rev. 73, 229-308.

Palucha, A., Branski, P., Pilc, A., 2004. Selective mGlu5 receptor antagonist MTEP attenuates naloxone-induced morphine withdrawal symptoms. Pol. J. Pharmacol. 56, 863-866.

Paoletti, P., Neyton, J., 2007. NMDA receptor subunits: function and pharmacology. Curr. Opin. Pharmacol. 7, 39-47.

Parelkar, N.K., Wang, J.Q., 2008. Upregulation of metabotropic glutamate receptor 8 mRNA expression in the rat forebrain after repeated amphetamine administration. Neurosci. Lett. 433, 250-254.

Paul, J.K., Athina, M., 2004. The ups and downs of addiction: role of metabotropic glutamate receptors. Trends Pharmacol. Sci. 25, 265-272.

Pennartz, C.M., Groenewegen, H.J., Lopes daSilva, F.H., 1994. The nucleus accumbens as a complex of functionally distinct neuronal ensembles: an integration of behavioural, electrophysiological and anatomical data. Prog. Neurobiol. 42, 719-761.

Perkinton, M.S., Sihra, T.S., Williams, R.J., 1999. $\mathrm{Ca}^{2+}$-permeable AMPA receptors induce phosphorylation of cAMP response element-binding protein through a phosphatidylinositol 3-kinase dependent stimulation of the mitogen-activated protein kinase signaling cascade in neurons. J. Neurosci. 19, 5861-5874.
Peters, J., Kalivas, P.W., 2006. The group II metabotropic glutamate receptor agonist, LY379268, inhibits both cocaine- and food-seeking behavior in rats. Psychopharmacology $186,143-149$.

Phillipson, O.T., Griffiths, A.C., 1985. The topographic order of inputs to nucleus accumbens in the rat. Neuroscience 16, 275-296.

Pierce, R.C., Kalivas, P.W., 1997. A circuitry model of the expression of behavioral sensitization to amphetamine-like psychostimulants. Brain Res. Rev. 25, 192-216.

Pierce, R.C., Pierce-Bancroft, A.F., Prasad, B.M., 1999. Neurotrophin-3 contributes to the initiation of behavioral sensitization to cocaine by activating the Ras/ mitogen-activated protein kinase signal transduction cascade. J. Neurosci. 19, 8685-8695.

Pin, J.P., Acher, F., 2002. The metabotropic glutamate receptors: structure, activation mechanism and pharmacology. Curr. Drug Target CNS Neurol. Disord. 1, 297317.

Pin, J.P., Duvoisin, R., 1995. Review: neurotransmitter receptors. I. The metabotropic glutamate receptors: structure and function. Neuropharmacology 34, 1-26.

Popik, P., Kolasiewicz, W., 1999. Mesolimbic NMDA receptors are implicated in the expression of conditioned morphine reward. Naunyn-Schmiedebergs Arch. Pharmacol. 359, 288-294.

Popik, P., Mamczarz, J., Fraczek, M., Widla, G., Hesselink, M., Danysz, W., 1998. Inhibition of reinforcing effects of morphine and naloxone-precipitated opioid withdrawal by novel glycine site and uncompetitive NMDA receptor antagonists. Neuropharmacology 37, 1033-1042.

Radwanska, K., Caboche, J., Kaczmarek, L., 2005. Extracellular signal-regulated kinase (ERKs) modulate cocaine-induced gene expression in the mouse amygdala. Eur. J. Neurosci. 22, 939-948.

Rasmussen, K., 1995. The role of the locus coeruleus and $N$-methyl-D-aspartic acid (NMDA) and AMPA receptors in opiate withdrawal. Neuropsychopharmacology 13, 295-300.

Ree, V.J.M., Gerrits, M.A.F.M., Vanderschuren, L.J.M.J., 1999. Opioids, reward and addiction: an encounter of biology, psychology, and medicine. Pharmacol. Rev. 51, 341-396.

Robbe, D., 2002. Metabotropic glutamate receptor 2/3-dependent long-term depression in the nucleus accumbens is blocked in morphine withdrawn mice. Eur. J. Neurosci. 16, 2231-2235.

Rong, R., Ahn, J.Y., Huang, H., Nagata, E., Kalman, D., Kapp, J.A., Tu, J., Worley, P.F. Snyder, S.H., Ye, K., 2003. PI3 kinase enhancer-Homer complex couples mGluRI to PI3 kinase, preventing neuronal apoptosis. Nat. Neurosci. 6, 1153-1161.

Roux, P.P., Blenis, J., 2004. ERK and p38 MAPK-activated protein kinases: a family of protein kinases with diverse biological functions. Microbiol. Mol. Biol. Rev. 68, 320-344.

Schoepp, D.D., Bockaert, J., Sladeczek, F., 1990. Pharmacology and functional characteristics of metabotropic excitatory amino acid receptors. Trends Pharmacol. Sci. $11,508-515$.

Schoepp, D.D., 2001. Unveiling the functions of presynaptic metabotropic glutamate receptors in the central nervous system. J. Pharmacol. Exp. Ther. 299, $12-20$.

Schoffelmeer, A.N., Wardeh, G., Vanderschuren, L.J., 2001. Morphine acutely and persistently attenuates non-vesicular GABA release in rat nucleus accumbens. Synapse 42, 87-94.

Schotanus, S.M., Chergui, K., 2008. Dopamine D1 receptors and group I metabotropic glutamate receptors contribute to the induction of long-term potentiation in the nucleus accumbens. Neuropharmacology 54, 837-844.

See, R.E., Fuchs, R.A., Ledford, C.C., McLaughlin, J., 2003. Drug addiction, relapse, and the amygdala. Ann. N.Y. Acad. Sci. 985, 294-307.

Seeburg, P.H., 1993. The molecular biology of glutamate receptor channels. Trends Pharmacol. Sci. 14, 297-303.

Shaham, Y., Rajabi, H., Stewart, J., 1996. Relapse to heroin-seeking in rats under opioid maintenance: the effects of stress, heroin priming, and withdrawal. J. Neurosci. 16, 1957-1963.

Shi, X., McGinty, J.F., 2006. Extracellular signal-regulated mitogen-activated protein kinase inhibitors decrease amphetamine-induced behavior and neuropeptide gene expression in the striatum. Neuroscience 138, 1289-1298.

Spanagel, R., Weiss, F., 2002. The dopamine hypothesis of reward: past and current status. Trends Neurosci. 22, 521-527.

Spiga, S., Serra, G.P., Puddu, M.C., Foddai, M., Diana, M., 2003. Morphine withdrawalinduced abnormalities in the VTA: confocal laser scanning microscopy. Eur. J. Neurosci. 17, 605-612.

Stephenson, F.A., 2006. Structure and trafficking of NMDA and $\mathrm{GABA}_{\mathrm{A}}$ receptors. Biochem. Soc. Trans. 34, 877-881.

Suaud-Chagny, M.F., Chergui, K., Chouvet, G., Gonon, F., 1992. Relationship between dopamine release in the rat nucleus accumbens and the discharge activity of dopaminergic neurons during local in vivo application of amino acids in the ventral tegmental area. Neuroscience 49, 63-72.

Sucher, N.J., Awobuluyi, M., Choi, Y.B., Lipton, S.A., 1996. NMDA receptors: from genes to channels. Trends Pharmacol. Sci. 17, 348-555.

Svensson, L., Zhang, J., Johannessen, K., Engel, J.A., 1994. Effect of local infusion of glutamate analogues into the nucleus accumbens of rats: an electrochemical and behavioural study. Brain Res. 643, 155-161.

Swanson, L.W., 1982. The projections of the ventral tegmental area and adjacent regions: a combined fluorescent retrograde tracer and immunofluorescence study in the rat. Brain Res. Bull. 9, 321-353.

Swanson, C.J., Kalivas, P.W., 2000. Regulation of locomotor activity by metabotropic glutamate receptors in the nucleus accumbens and ventral tegmental area. J. Pharmacol. Exp. Ther. 292, 406-414. 
Temple, A., Zukin, R.S., 1987. Neuroanatomical patterns of the $\mu, \delta$, and $\kappa$ opioi receptors of rat brain as determined by quantitative in vitro autoradiography. Proc. Natl. Acad. Sci. U.S.A. 84, 4308-4312.

Tingley, W.G., Ehlers, M.D., Kameyama, K., Doherty, C., Ptak, J.B., Riley, C.T., Huganir, R.L., 1997. Characterization of protein kinase $A$ and protein kinase $C$ phosphorylation of the $\mathrm{N}$-methyl-D-aspartate receptor NR1 subunit using phosphorylation site-specific antibodies. J. Biol. Chem. 272, 5157-5166.

Tokuyama, S., Wakabayashi, H., Ho, I.K., 1996. Direct evidence for a role of glutamate in the expression of the opioid withdrawal syndrome. Eur. J. Pharmacol. 295, $123-129$.

Tokuyama, S., Zhu, H., Oh, S., Ho, I.K., Yamamoto, T., 2001. Further evidence for a role of NMDA receptors in the locus coeruleus in the expression of withdrawa syndrome from opioids. Neurochem. Int. 39, 103-109.

Tonini, R., Ciardo, S., Cerovic, M., Rubino, T., Parolaro, D., Mazzanti, M., Zippel, R., 2006. ERK-dependent modulation of cerebellar synaptic plasticity after chronic $\Delta 9$-tetrahydrocannabinol exposure. J. Neurosci. 26, 5810-5818.

Trujillo, K.A., Akil, H., 1991. Inhibition of morphine tolerance and dependence by the NMDA receptor antagonist MK-801. Science 251, 85-87.

Tsuji, M., Nakagawa, Y., Ishibashi, Y., Yoshii, T., Takashima, T., Shimada, M., Suzuki, T., 1996. Activation of ventral tegmental $\mathrm{GABA}_{\mathrm{B}}$ receptors inhibits morphineinduced place preference in rats. Eur. J. Pharmacol. 313, 169-173.

Tzschentke, T.M., Schmidt, W.J., 2000. Functional relationship among medial prefrontal cortex, nucleus accumbens, and ventral tegmental area in locomotion and reward. Crit. Rev. Neurobiol. 14, 131-142.

Tzschentke, T.M., Schmidt, W.J., 2003. Glutamatergic mechanisms in addiction. Mol. Psychiatry $8,373-382$.

Tzschentke, T.M., 2001. Pharmacology and behavioral pharmacology of the mesocortical dopamine system. Prog. Neurobiol. 63, 241-320.

Ungless, M.A., Whistber, J.L., Malenka, R., Bonci, A., 2001. Single cocaine exposure in vivo induces long-term potentiation in dopamine neurons. Nature 411, 583587.

Valjent, E., Corbille, A.G., Bertran-Gonzalez, J., Herve, D., Girault, J.A., 2006. Inhibition of ERK pathway or protein synthesis during reexposure to drugs of abuse erases previously learned place preference. Proc. Natl. Acad. Sci. U.S.A. 103, 2932-2937.

Valjent, E., Corvol, J.C., Pages, C., Besson, M.J., Maldonado, R., Caboche, J., 2000. Involvement of the extracellular signal-regulated kinase cascade for cocainerewarding properties. J. Neurosci. 20, 8701-8709.

Valjent, E., Pascoli, V., Svenningsson, P., Paul, S., Enslen, H., Corvol, J., Stipanovich, A. Caboche, J., Lombroso, P.J., Nairn, A.C., Greengard, P., Hervé, D., Girault, J., 2005. Regulation of a protein phosphatase cascade allows convergent dopamine and glutamate signals to activate ERK in the striatum. Proc. Natl. Acad. Sci. U.S.A. $102,491-496$

Van Bockstaele, E.J., Pickel, V.M., 1995. GABA-containing neurons in the ventral tegmental area project to the nucleus accumbens in rat brain. Brain Res. 682, $215-221$.

Vaupel, D.B., Kimes, A.S., London, E.D., 1997. Further in vivo studies on attenuating morphine withdrawal: isoform-selective nitric oxide synthase inhibitors differ in efficacy. Eur. J. Pharmacol. 324, 11-20.

Voorn, P., Brady, L.S., Schotte, A., Berendse, H.W., Richfield, E.K., 1994. Evidence for two neurochemical divisions in the human nucleus accumbens. Eur. J. Neurosci. 6, 1913-1916

Wang, B., Luo, F., Ge, X.C., Fu, A.H., Han, J.S., 2002. Effects of lesions of various brain areas on drug priming or footshock-induced reactivation of extinguished conditioned place preference. Brain Res. 950, 1-9.

Wang, H.L., Xiang, X.H., Guo, Y., Wu, W.R., Cao, D.Y., Wang, H.S., Zhao, Y., 2005. Ionotropic glutamatergic neurotransmission in the ventral tegmental are modulates $\Delta$ FosB expression in the nucleus accumbens and abstinence syndrome in morphine withdrawal rats. Eur. J. Pharmacol. 527, 94-104.

Wang, H.L., Zhao, Y., Xiang, X.H., Wang, H.S., Wu, W.R., 2004. Blockade of ionotropic glutamatergic transmission in the ventral tegmental area attenuates the physical signs of morphine withdrawal in rats. Prog. Neuropsychopharmacol. Biol. Psychiatry 28, 1079-1087.

Wang, J.Q., Fibuch, E.E., Mao, L., 2007. Regulation of mitogen-activated protein kinases by glutamate receptors. J. Neurochem. 100, 1-11.

Wang, J.Q., Tang, Q., Parelkar, N.K., Liu, Z., Samdani, S., Choe, E.S., Yang, L., Mao, L., 2004. Glutamate signaling to Ras-MAPK in striatal neurons. Mol. Neurobiol. 29, 1-14.
Wang, M.Y., Rampil, I.J., Kendig, J.J., 1999. Ethanol directly depresses AMPA and NMDA glutamate currents in spinal cord motor neurons independent of actions on $\mathrm{GABA}_{\mathrm{A}}$ or glycine receptors. J. Pharmacol. Exp. Ther. 290, 362-367.

Watanabe, T., Nakagawa, T., Yamamoto, R., Maeda, A., Minami, M., Satoh, M., 2002. Involvement of glutamate receptors within the central nucleus of the amygdala in naloxone-precipitated morphine withdrawal-induced conditioned place aversion in rats. Jpn. J. Pharmacol. 88, 399-406.

Weiss, F., Baptista, M., 2003. mGlu2/3 agonist (LY379268) selectively reverses conditioned reinstatement of cocaine seeking behavior. Behav. Pharmacol 14, S27.

Whistler, J.L., von Zastrow, M., 1999. Dissociation of functional roles of dynamin in receptor-mediated endocytosis and mitogenic signal transduction. J. Biol. Chem. 274, 24575-24578.

White, F.J., 1996. Synaptic regulation of mesocorticolimbic dopamine neurons. Ann. Rev. Neurosci. 19, 405-436.

Wise, R.A., 1996. Neurobiology of addiction. Curr. Opin. Neurobiol. 6, 243-251.

Wolf, M.E., 1998. The role of excitatory amino acids in behavioral sensitization to psychomotor stimulants. Prog. Neurobiol. 54, 679-720.

Wong, C.S., Cherng, C.H., Luk, H.N., Ho, S.T., Tung, C.S., 1996. Effects of NMDA receptor antagonists on inhibition of morphine tolerance in rats: binding at muopioid receptors. Eur. J. Pharmacol. 297, 27-33.

Xi, Z.X., Stein, E.A., 1998. Nucleus accumbens dopamine release modulation by mesolimbic $\mathrm{GABA}_{\mathrm{A}}$ receptors-an in vivo electrochemical study. Brain Res. 798, 156-165.

Xi, Z.X., Stein, E.A., 1999. Baclofen inhibits heroin self-administration and mesolimbic dopamine release. J. Pharmacol. Exp. Ther. 290, 1369-1374.

Xi, Z.X., Stein, E.A., 2002a. Blockade of ionotropic glutamatergic transmission in the ventral tegmental area reduces heroin reinforcement in rat. Psychopharmacology $164,144-150$.

Xi, Z.X., Stein, E.A., 2002b. GABAergic mechanisms of opiate reinforcement. Alcohol Alcohol. 37, 485-494.

Xiao, B., Tu, J.C., Worley, P.F., 2000. Homer: a link between neural activity and glutamate receptor function. Curr. Opin. Neurobiol. 10, 370-374.

Xu, L., Zhao, Y., Zhan, S.Q., Tang, X.D., Guo, Y., Wang, H.S., Yang, C., 2007. Temporal and spatial expression of preprotachykinin A messenger RNA in the developing filial mice brain after maternal administration of monosodium glutamate at a late stage of pregnancy. Neuroscience 145, 974-980.

Yamaguchi, T., Sheen, W., Morales, M., 2007. Glutamatergic neurons are present in the rat ventral tegmental area. Eur. J. Neurosci. 25, 106-118.

Yamakura, T., Sakimura, K., Shimoji, K., 1999. Direct inhibition of the $N$-methyl-Daspartate receptor channel by high concentrations of opioids. Anesthesiology 91, 1053-1063.

Young, A.B., Fagg, G.E., 1990. Excitatory amino acid receptors in the brain: membrane binding and receptor autoradiographic approaches. Trends Pharmacol. Sci. 11, 126-133.

Youngren, K.D., Daly, D.A., Moghaddam, B., 1993. Distinct actions of endogenous excitatory amino acids on the outflow of dopamine in the nucleus accumbens. J. Pharmacol. Exp. Ther. 264, 289-293.

Zarrindast, M.R., Mousa-Ahmadi, E., 1999. Effects of GABAergic system on naloxoneinduced jumping in morphine-dependent mice. Eur. J. Pharmacol. 381, 129-133.

Zhang, L., Lou, D., Jiao, H., Zhang, D., Wang, X., Xia, Y., Zhang, J., Xu, M., 2004. Cocaineinduced intracellular signaling and gene expression are oppositely regulated by the dopamine D1 and D3 receptors. J. Neurosci. 24, 3344-3354.

Zhang, O. Zhao, Y., Guo, Y, Cao, D.Y. Tian, Y.L, Yao, F.R., Wang, H.S, 2006 Electrophysiological evidence for the interaction of substance $P$ and glutamate on $A \delta$ and $C$ afferent fibre activity in rat hairy skin. Clin. Exp. Pharmacol. Physiol. 33, 1128-1133.

Zhou, Q., Frandberg, P.A., Kindlundh, A.M., Greves, P.L., Nyberg, F., 2003. Substance $\mathrm{P}(1-7)$ affects the expression of dopamine D2 receptor mRNA in male rat brain during morphine withdrawal. Peptides 24, 147-153.

Zhou, Q. Nyberg, F. 2002. Injection of substance P (SP) N-terminal fragment SP(17 ) into the ventral tegmental area modulates the levels of nucleus accumbens dopamine and dihydroxyphenylacetic acid in male rats during morphine withdrawal. Neurosci. Lett. 320, 117-120.

Zhu, H., Barr, G.A., 2004. The role of AMPA and metabotropic glutamate receptors on morphine withdrawal in infant rats. Int. J. Dev. Neurosci. 22, 379-395.

Zhu, H., Rockhold, R.W., Ho, I.K., 1998. The role of glutamate in physical dependence on opioids. Jpn. J. Pharmacol. 76, 1-14. 